\title{
Importance of Tropical Homegardens Agroforestry System
}

\author{
Vikas Kumar $^{1 *}$ and Anjali Tiwari \\ ${ }^{1}$ Department of Silviculture and Agroforestry, College of Forestry, Vellanikkara, \\ Kerala Agricultural University, KAU, Thrissur, Kerala 680656, India \\ ${ }^{2}$ Department of agriculture and Forestry, Dr. K.N. Modi University, Rajasthan- 304021, India \\ *Corresponding author
}

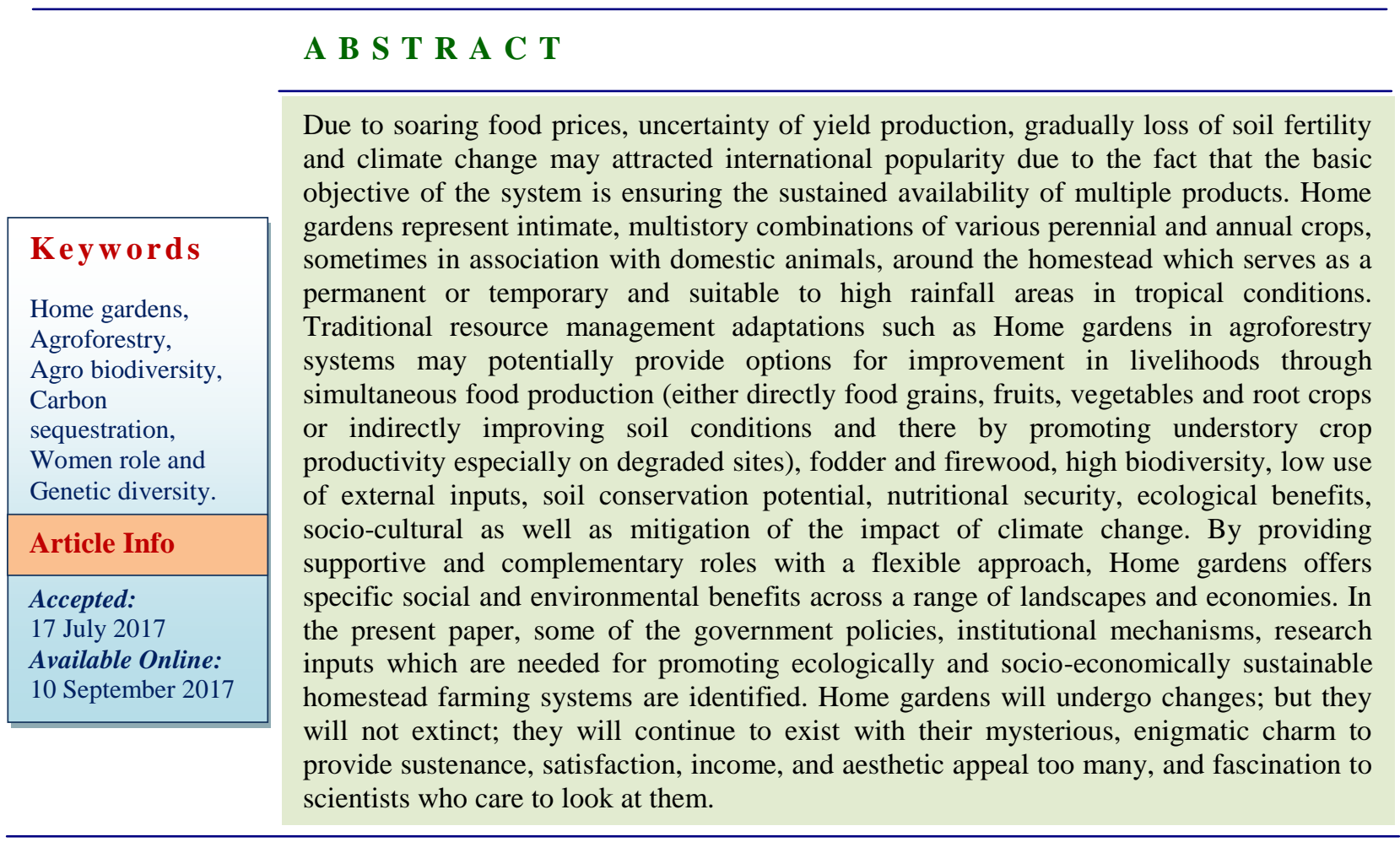

\section{Introduction}

Agroforestry refers the sustainable land use system that combines arable crops with tree crops and/ or livestock on the same land management unit, either spatially or temporally (Torquebiau and Penot, 2006). It is a collective name for land-use systems involving trees combined with arable crops and/or animals on the and practices where woody perennials are deliberately used on the same land management system as agricultural crops and/or animals, in a spatial or temporal sequence, there being both ecological and economic interaction between the components (Kumar, 2016a). In the realm of agroforestry, Homegardens and other multistrata, multispecies associations occupy an odd place. They are the most elaborate manmade, tree-crop-animal associations, resembling a 
natural ecosystem and offer valuable ecosystem functions with human interference (Kumar and Tripathi, 2017). In almost all tropical and subtropical eco zones agroforestry is represented by the homestead farming, essentially the mixed cropping of annual and perennial crops around the farmer's dwelling houses. Homegardens are recognized worldwide as an epitome of a sustainable agroforestry system (Torquebiau, 1992; Kumar et al., 1994; Kumar and Nair, 2004; Soumya et al., 2007; Galluzzi et al., 2010). From a system-dynamics point of view, the concept of sustainability includes two main dimensions: ecological sustainability (in the sense of keeping within ecological stability domains) and social sustainability (in the sense of adjusting to social dynamics) (Wiersum, 1995; Das and Das, 2005; Kumar, 2017). Researchers mostly focused on ecological sustainability rather than social sustainability (Kumar and Nair, 2004). Tropical Homegardens are typically such unique land-use systems involving the deliberate management of multipurpose trees and shrubs in intimate association with herbaceous species (mainly annual, perennial, and seasonal agricultural crops), and livestock, all managed within the compounds of individual homes. It is a traditional land use practice around a homestead where several plant species are maintained by members of the household and their products are intended primarily for household consumption (Shrestha et al., 2001). Homegardens occupies an area around 0.20 to 0.50 hectare. In addition to efficient nutrient cycling, high biodiversity, low use of external inputs and soil conservation potential (Lakshmi and Joseph, 2017), they provide a diverse and stable supply of socioeconomic products and benefits to the families that maintain them.

In spite, or perhaps because of the pre-historic origin of the practice, accurate data on the extent of area under Homegardens is not available. Estimating the area of Homegardens is beset with several problems (Kumar, 2006). The lack of boundaries between Homegardens and adjoining agricultural fields i.e. difficult to determine where Homegardens end and other cultivated fields begin (Abebe et al., 2006). In spite of these difficulties, some efforts have been made in compiling statistics on the spread of Homegardens. Such estimates include 5.13 million ha of land under Pekarangans in Indonesia, 0.54 million ha under homesteads in the Bangladesh, 1.05 million ha in Sri Lanka, and 1.44 million ha in Kerala, India (Kumar, 2006). For instance in Kerala, homestead farming covers about $88 \%$ of the total landholding and about $41 \%$ of the total cultivable area of the Kerala (KLUB, 1989), while it covers about $14 \%$ of the total area of the Sri Lanka (Senanayake et al., 2009). Depending on the nature, type of components, most Homegardens in the tropics can be classified as agro silvopastoral system consisting of herbaceous crops, woody perennials and animals. Some Homegardens represent agri silvicultural system consisting only of the first two components. However, Homegardens are not static, but have evolved over centuries; thanks to adaptive abilities of farmers in responding to changing rural and livelihood conditions (Wiersum, 2006). The average size of a home garden in tropical and subtropical regions is much less a hectare (Fernandes and Nair, 1986; Nair and Sreedharan, 1986; Babu et al., 1992; Kumar et al., 1994; Sankar and Chandrashekara, 1997; Mendez et al., 2001; Leiva et al., 2002; Quiroz et al., 2002; Abebe, 2005; Das and Das, 2005; Kumar, 2006; Pandey et al., 2006; Saha et al., 2009; Sahoo et al., 2010; Kumar, 2011; Devi and Das, 2012; Saikia et al., 2012; Kunhamu et al., 2015), indicating the subsistence of the practice. It may be mentioned here that very often such small sized land use systems with monocropping 
are not viable, particularly in the rural ecosystems (Jose and Shanmugaratnam, 1993). Existence and the predominance of home garden agroforestry since time immemorial in several tropical countries is the evidence to show that this system of land use is an ecological and socio-economic adaptive system. In the present paper, some of the government policies, institutional mechanisms, research inputs which are needed for promoting ecologically and socioeconomically sustainable homestead farming systems are identified.

\section{Importance of species diversity in homegardens}

Homegardens has high potential for in situ conservation of genetic resources (Watson and Eyzaguirre, 2002; McNeely, 2004; Schroth et al., 2004; Kumar, 20011, Kunhamu et al., 2015; Rana et al., 2016; Gariya et al., 2017). The extant specieslisting-dominated literature on Homegardens, is the continuous interaction of species domestication. Simons and Leakey (2004) describe the deliberate selection and management of trees (domestication) by humans that has been going on for millennia in agroforestry systems. Eyzaguirre and Watson (2001) reported that Homegardens are micro-environments with high diversity of species, varieties and gene, which constitute important source of food, fodder, fuel, medicines, spice and construction materials for household owner. Biodiversity (Short form for biological diversity) is often used as a synonym for species diversity. The importance of maintaining biodiversity in sustaining food production and protecting human and ecosystem health is now universally recognized, and land use systems that promote biodiversity are considered to be quite desirable from that perspective. A classification based on the production systems and species diversity ranked Homegardens top with its highest biological diversity among all manmade agroecosystem (Swift and Anderson, 1993; Kumar, 2018). It is reasonable to assume that much of this in situ domestication has taken place in Homegardens. It is also likely that similar patterns of domestication have happened for other plant species in Homegardens around the world, especially in those with long history as in South and Southeast Asia (Wiersum, 2004).

The structure, composition and diversity of Homegardens results from the influence of socioeconomic factors as well as surrounding geographical and ecological condition (Kehlenbeck and Maass, 2004; Sunwar et al., 2006; Kumar et al., 2016). The herbaceous species diversity including medicinal species in Homegardens primary depends on climate, altitude, socioeconomic and cultural factors, and nearness to markets (Kumar et al., 2016). The diversity and density of generally increase with rainfall and elevation (Rao and Rajeswara Rao, 2006). Homegardens is glorious examples of species diversity in cultivated and managed plant communities (Kumar and Nair, 2004). Homegardens in West Java, Indonesia, contained the greatest diversity with an average number of 56 species per garden, the number of species being more in the wet season than in the dry season (Soemarwoto, 1987). In Bangladesh, species number decreased with increase in Homegardens size and from deltaic region to dry region (Millat-e-Mustafa et al., 2002). In Venezuela, high diversity was positively correlated with age and remoteness of the garden, its use for subsistence, age of the farmer, and extent of participation of family labour in the activities of the garden (Mulas et al., 2004). Tropical Homegardens is important sites of high plant diversity and may act as reservoirs of crop germplasm (Coomes and Ban, 2004). Asahira and Yazawa (1981) reported a total of 200 kinds 
of useful plants including vegetables, especially various root vegetables, herbs, spices, fruit trees, fiber crops cultivated in a tropical Asian home garden, approximately 0.25 acres in size. Over 170 species were recorded from an inventory made in randomly selected 228 Homegardens in Kerala (Sankar and Chandrashekara, 2002). Inventory of plants in the live fences alone of 60 Homegardens enabled to register 68 species (Chandrashekara et al., 1997). Jose (1991) listed 179 species from 80 Homegardens in a village in Kerala. These include 71 tree species, 6 perennial herbaceous crops, 23 annual crop species, 18 medicinal plant and 61 ornamental plants. During a survey conducted in a homestead of about 1ha in size in the Central agroclimatic zone of Kerala, 124 plant species were encountered of which 60 were tree species (Chandrashekara, 1995). High diversity of 463 species from high rainfall humid central Kerala, of which 208 were trees, 86 shrubs and 169 herbs (Kumar, 2011). Such variable accounts of species diversity have been reported from other parts of India as well. 122 species from Homegardens in Barak valley of Assam (Das and Das, 2005), while high figure of 294 species from the upper Assam (Devi and Das, 2012). Structural and functional features of the peri-urban Homegardens of southern Kerala, India where 90 Homegardens with 30 each belonging to three holding size classes viz. large (>0.08 ha), medium (0.04-0.08 ha) and small (0-0.04 ha) were surveyed from Neyyatinkara Municipality area, Trivandrum. Altogether, 95 species were recorded belonging to 80 genera and 35 families in large Homegardens. Shannon's diversity index was $3.77,3.23$ and 3.87 respectively for large, medium and small Homegardens and respective value for Simpsons Dominance Index $0.92,0.89$ and 0.81 . The average tree density of small, medium and large classes was 147, 165 and 76 and number of species per home garden was 24, 48 and 94, respectively (Kunhamu et al., 2015). Recent reports indicated on agrobiodiversity, structural compositions and species utilization of Homegardens in humid tropics has highest 525 plant species, represented 320 genera and 102 families, of which 237 were trees (> 20 cm GBH) (140 genera and 49 families), 100 shrubs (62 genera and 32 families) and 187 herbs (138 genera and 54 families) in the 330 Homegardens of Thrissur, Kerala, India in subset of small, medium, and large Homegardens, respectively (Kumar, 2018). All these observations indicate that the Homegardens are perpetual 'experimentors' and constantly trying and testing new species (Ninez, 1987).

In general, in a home garden, both cultivated and naturally growing plants can be seen; most of the naturally growing plants are not managed by the Homegardens. Data collected on the management of naturally growing species in Homegardens of Kerala (Chandrashekara and Baiju, 2010) has revealed that about $65 \%$ - $83 \%$ of total number of such species in mixed species Homegardens and only 20\%-30\% in single species dominant Homegardens are managed. In addition, about $44 \%$ to $77 \%$ of total number of naturally growing species is put under some uses. According to Saikia et al., (2012) Homegardens also serve to conserve rare and threatened species and varieties. However, inventory of floristic diversity in Homegardens in Kerala revealed that generally Homegardens are playing negligible role in conserving wild species diversity. On the other hand, Homegardens are the informal experimental stations for transfer, trial and adaptation of domesticated species. Similarly, these Homegardens represent a 'genetic backstop', preserving species and varieties that are not economic in field production and are planted in small scale for reasons of taste preference, tradition, or availability of planting materials. Such an analysis may also 
be extended specifically to other tropical Homegardens in order to appreciate the importance of home garden agroforestry in conserving and utilizing biodiversity.

\section{Importance of structure and composition in homegardens}

Homegardens hve been commonly characterized as biodiversity and sustainable land us systems (Soemarwoto, 1987; Torquebiau, 1992; Kumar and Nair, 2004). It has been acknowledged that this does not mean that the structure and composition of Homegardens should be assumed as being stable (Kumar and Nair, 2004). From an ecological point of view, the production processes are not necessarily negatively affected by changes in vegetation structure and composition, if the nutrient cycling processes, hydrological conditions, and synergetic relations are not compromised. From a social point of view, the concept of sustainability incorporates the nation of adaptation to social change (Peyre et al., 2006). Homegardens has faced with constant pressure of change brought about by demographic, economic, technological, and social dynamics, and they are constantly adopted to changing livelihoods.

At first sight, Homegardens seem to lack structure as trees, shrubs and herbaceous plants grow in a complex mixture without any clear pattern (Brierley, 1976). However, a closer look at the vegetation shows that plants do seem to be organized in different patterns or layers. Thus, Homegardens is also called as "Multi-tier system" or "Multi-tier-cropping" as it consists of different canopy strata (Figure 1). For instance, five canopy strata have been identified in the Homegardens of Kerala. The first layer lies within $2 \mathrm{~m}$ high from the ground and is constituted by vegetables (Cajanus cajan (pigeon pea), Arachis hypogaea (peanuts), Phaseolus,
Psophocarpus and Vigna species (beans and other legumes)), tuber crops (Colocasia esculenta (taro), Dioscorea alata (greater yam), Dioscorea esculenta (sweet yam), Ipomoea batatas (sweet potato), Manihot esculenta (cassava), Xanthosoma species (tannia or cocoyam)), grasses (Cymbopogon citratus (lemon grass)), spices (Zingiber officinale (ginger), Kasthuri manjal (kasthuri), Piper methysticum (kava), Curcuma longa (turmeric), Cinnamomum zeylanicum (cinnamon), Areca catechu (betel nut), Piper betle (betel vine)) and other herbaceous plants (Ananas comosus (pineapple), Passiflora edulis (passion fruit), Saccharum officinarum (sugarcane), Zea mays (corn or maize)). The second and third layers (within $2 \mathrm{~m}$ to $10 \mathrm{~m}$ high from the ground) are almost continuous and overlapping each other. Some of the common constituents of these layers in Kerala Homegardens are banana, nutmeg, papaya, mango, cocoa, young coconut palms and saplings of trees. The upper most canopy layer is formed by Anacardium occidentale (cahew nut), Artocarpus heterophyllus (jackfruit), Citrus species (lemon, lime, orange and tangerin), Annona species (soursop and sweetsop), Swietenia macrophylla (mahogany), Ailanthus triphysa (tree of heaven), Averrhoa carambola (carambola), A. altilis (breadfruit), Carica papaya (papaya), Psidium guajava (guava), Mangifera indica (mango), Azadirachta indica (neem), Musa species (bananas and plantains), Persea americana (avocado), Cocus nucifera (coconut), Spondias dulcis, Syzygium malaccense (malay apple), Tamarindus indica (tamarind), Hevea brasiliensis (rubber), and other tall trees at about $10 \mathrm{~m}$ to $25 \mathrm{~m}$ height (Figure 2). However the choice species is determined by the agroclimatic and farmers' socio-economic conditions. Analysis of area occupied by canopy cover of different constituents indicated that in tradition Homegardens, which are not less than 40-45 year old, the 
crown to land ratio ranged from 210 to $88 \%$ (Sankar and Chandrashekara, 2002). Several studies in Asia indicated that with commercialization, often a gradual change from subsistence to commercial crops occurs in Homegardens, while the crop diversity decreases (Michon and Mary, 1994; Kumar and Nair, 2004; Das and Das, 2005; Peyre et al., 2006; Abdoellah et al., 2006; Kumar, 2011; Kunhamu et al., 2015) while reverse result reported by (Kumar, 2018).

\section{Importance of food and nutritional security in homegardens}

The Homegardens agroforestry system play a major role in food production in two ways: directly by providing edible products such as fruits, and indirectly by supporting food production through enhancing the soil's ability to support agriculture. A large number of fruit producing trees are integral parts of traditional homestead and other agroforestry farming systems with their characteristic multistrata canopies in many developing countries (Kumar and Nair, 2006). Although several of these fruit trees have not been studied scientifically and are thus underexploited and little known outside their habitat, they make significant contributions to food and nutritional security (Nair, 2008).

\section{Importance of women in homegardens}

Women play an important role in introducing many crops, particularly in the nearest surroundings of Homegardens. However, in general men have an upper hand over women in decision making in terms of introduction of cash crops and perennial trees. The role of women in home garden management depends on factors like their occupation, size of the Homegardens, opportunities for off-farm jobs and socio-economic condition of the family. For instance, Homegardens is the best example where, women contribute more labour to homestead farms than men. It is estimated that about $94 \%$ of the total female labour days was constituted by family labour (Jose, 1991). This 94\% of the female labour (family labour) forms $41 \%$ of the total labour employed in the homestead farm in a year. Since this is unpaid labour, it is not given due value, and is not included in any statistics and thus become invisible. The emerging agricultural scenario and the trends in Kerala' cropping pattern, the drastic transition from subsistence to cash crop monocultures would increasingly marginalize women. Women's work would become more burdensome and less socially valued (Dunkelman and Davidson, 1988). Sankar and Chandrashekara (2002) recorded that in about $60 \%$ of total number of small Homegardens $(<0.4$ ha $)$ women contribute significantly for the management of the system. They also reported that only in $22 \%$ and $12 \%$ respectively of total number of medium sized Homegardens (0.41- 0.12ha) and large Homegardens (>1.2ha) the role of women in garden management is significant. Women were participated very actively in different activities like agriculture (90\%), horticulture $(85 \%)$, livestock managing $(90 \%)$ and household activities (85\%). Almost $50 \%$ of the rural households in the hills were headed by women as the men folk migrated to augment the farm income in Bhimtal block of Nainital District, Uttarakhand, India (Gariya et al., 2016) while in Garhwal region of Uttarakhand, primary roles of women were crop management (74.8\% of households) and harvesting $(55.7 \%)$, with smaller role in marketing (36.6\%) (Rana et al., 2017). Women role in using money to pay debts and buy agricultural production inputs was less significant (Arifin et al., 2012).The marginalization process would be accelerated where there is a desperate and pervasive need for cash to meet family needs. If those needs can only be supplied by the market, unpaid traditional roles would no longer evoke 
respect, thereby undercutting the authority of women (Huston, 1985).

\section{Importance of biodiversity for the economy in homegardens}

The Homegardens seldom meet the entire basic-staple-food needs of the family. However, they are complementary to other crop lands. Thus Homegardens are a component of the larger farming system of the household. Indeed, if the home garden is the only land available to the household, food crops such as cassava will dominate the species composition of the garden (Kumar and Nair, 2004). It is estimated that about $50 \%$ of the total number of Homegardens contribute less than $25 \%$ of the total income of the household (Sankar and Chandrashekara, 2002). On the other hand, about $32 \%$ and $20 \%$ of total number of Homegardens studied contributed about $25 \%$ - $50 \%$ and $>50 \%$ of the household income respectively. However, the contribution of Homegardens for the state economy of wood and bamboo is significant. For instance, according to Krishnankutty (1990) homesteads provide $74 \%$ to $84 \%$ of wood requirements in Kerala. Similarly the traditional Homegardens constitute a principal source of bio-fuels for the rural households (Table 1). For example $51 \%$ of the fuel-wood collected in various geographical regions are derived from Homegardens (Shanavas and Kumar, 2003). Analysis of supply and demand of bamboo in Kerala State indicated that during the year 1993-94 the estimated demand for bamboo was $1,69,000$ metric tons. Of the total supply of bamboo in State, Homegardens contributed $63 \%$ and forests the remaining $37 \%$ (Krishnankutty, 1998). Homegardens of Kerala are also recognized as repositories of non-timber products such as medicinal and aromatic plants, ornamentals, gums, resins, chemical extractives and green leaf manure. It may also be mentioned here that very often yield of a crop in a given home garden may be more than the requirement for home consumption, and the excess quantity may not be enough to sell in the market. In such a situation, farmers exchange their crops among themselves or offer to those who do not have such items. In some parts of Kerala, it was also recorded that Homegardens who are having bamboo clumps in their gardens cut branches of bamboo during the months of December and January and use the thorny branches to fence their crop lands. They also offer the bamboo branches to their relatives and friends for the same purpose. In addition, several crops of Homegardens in Kerala are often instrumental to link heterogeneous communities in the village ecosystem. For instance, the bamboo weaving communities obtain suitable bamboo poles from the Homegardens and weave items such as bamboo mats, baskets, fish nets etc. While some of these items are offered to those supplied the raw materials, rest will be sold by the weavers. Thus homestead bamboo, like many other crops is one element in a complex system of rural relationships where human beings are the main actors.

\section{Importance of carbon sequestration in homegardens}

Most discussions on carbon sequestration potential of Homegardens and, indeed agroforestry systems in general are based more on hypothetical considerations than empirical results. The role of land use systems in capturing atmospheric carbon dioxide $\left(\mathrm{CO}_{2}\right)$ and storing the $\mathrm{C}$ in plant parts and soil became an important area of research during the past decade. Agroforestry systems have indirect effects on carbon sequestration because they reduce harvesting pressure on natural forests which are the largest sinks for terrestrial carbon (Kumar, 2015a). 
Table.1 Traditional practices of homestead bamboo cultivation and their benefits to farmers (Based on Chandrashekara, 1996)

\begin{tabular}{|l|l|}
\hline \multicolumn{1}{|c|}{ Practice } & \multicolumn{1}{|c|}{ Benefits } \\
\hline $\begin{array}{l}\text { 1. Cultivation of bamboo in a } \\
\text { corner of homestead }\end{array}$ & $\begin{array}{l}\text { Freedom of movement for gardener within the } \\
\text { garden: more space available from other crops }\end{array}$ \\
\hline $\begin{array}{l}\text { 2. Trenching around the bamboo } \\
\text { clump }\end{array}$ & $\begin{array}{l}\text { Restriction of horizontal spread of bamboo roots } \\
\text { thereby reducing competition with other crops }\end{array}$ \\
\hline $\begin{array}{l}\text { 3. Mounding of soil around } \\
\text { clump }\end{array}$ & Stimulation of production of new culms \\
\hline $\begin{array}{l}\text { 4. Detopping of culms } \\
\text { 5. Intercropping with shade } \\
\text { tolerant, short duration crops }\end{array}$ & $\begin{array}{l}\text { Reduction of shading to other crops; formation of } \\
\text { longer axillary branches useful for fencing } \\
\text { crops can be harvested before the season of } \\
\text { bamboo branch cutting so that risks of damage } \\
\text { caused to the crops during the bamboo branch } \\
\text { cutting process. These crops are also suitable for } \\
\text { cultivation on raised beds, so reducing root } \\
\text { competition with bamboo }\end{array}$ \\
\hline
\end{tabular}

Fig.1 Tropical Homegardens: Multistrata composition of various components (Coconut, Mahogany, Papaya, Banana with intercropping of medicinal plants) with animal husbandry, piggery and fisheries component (Source: Kumar, 2018)

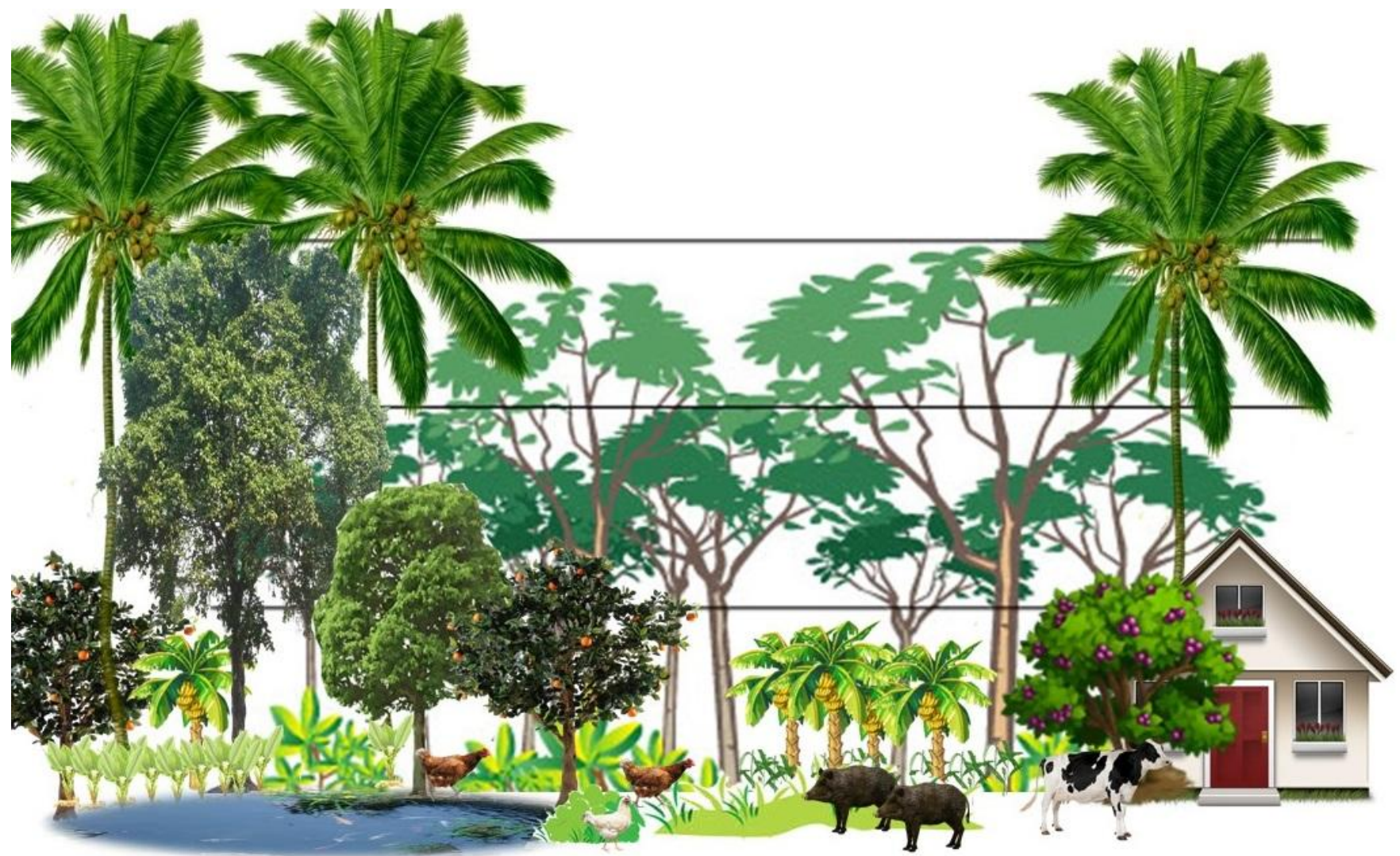


Fig.2 A typical Intercropping Homegardens System: A. Areca catechu (Areca nut) medicinal plant intercropping system; B. Cocus nucifera (coconut) - Kasthuri manjal (kasthuri) intercropping system; C. Cocus nucifera (coconut) - Myristica fragrans (nutmeg), and D. Swietenia macrophylla (mahogany) - Zingiber officinale (ginger) intercropping system.

(Source: Kumar et al., 2016)

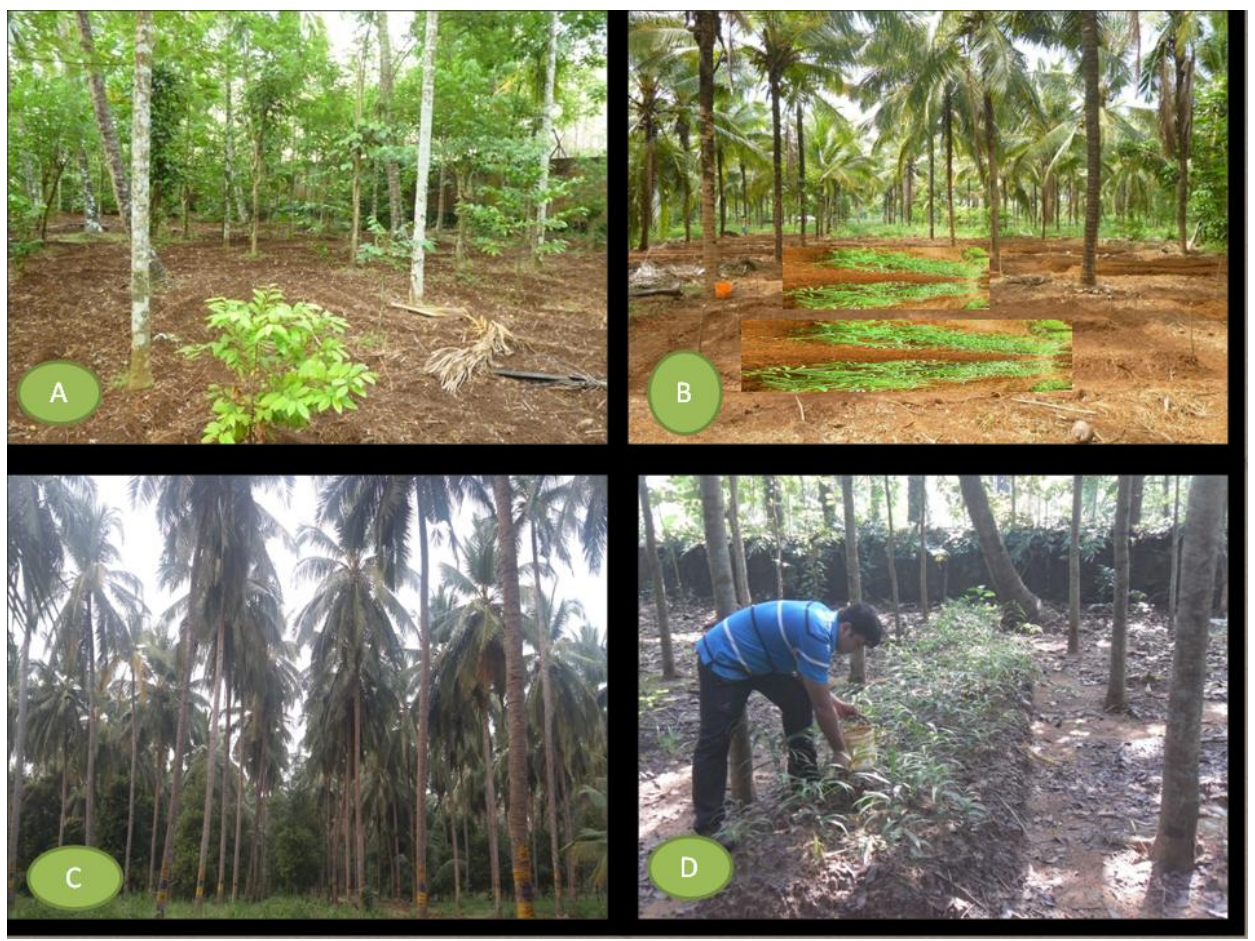

Fig.3 A schematic presentation of the major mechanisms and processes involved in production and service attributes of sustainable Homegardens (Source Kumar and Tripathi, 2017)

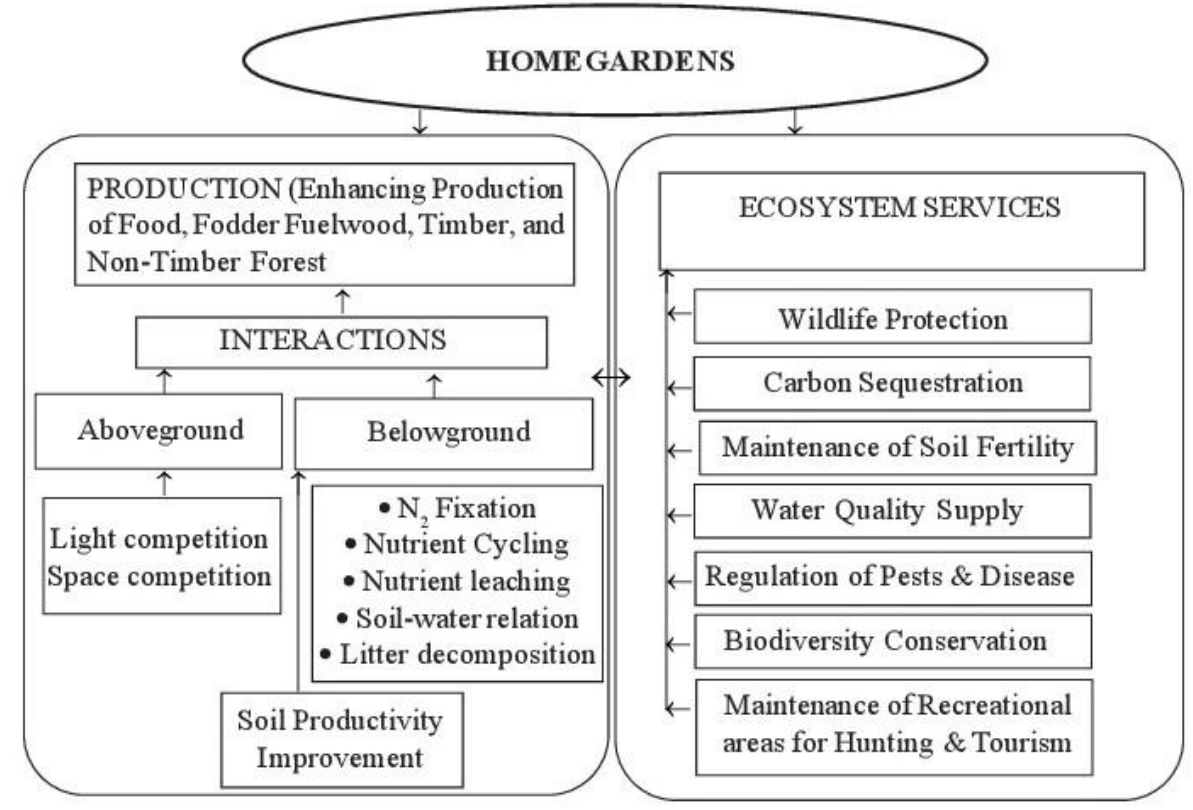


Agroforestry attracted special attention as a C sequestration strategy following its recognition as a $\mathrm{C}$ sequestration activity under the afforestation and reforestation activities of the Kyoto Protocol. This was in recognition of the perceived advantages of the large volume of aboveground biomass and deep root systems of trees in accomplishing that task. The amount of carbon in the above ground and below ground biomass of an agroforestry system is generally much higher than in an equivalent land-use system without trees (Murthy et al., 2013). In another estimate agroforestry contributes $19.30 \%$ of total $\mathrm{C}$ stock under different land uses. The potential of agroforestry systems as carbon sink varies depending upon the growth and nature of the tree species, species composition, age of trees, geographic location, local climatic factors and management regimes. The growing body of literature indicates that agroforestry systems has the potential to sequester large amounts of above and below ground carbon in addition to soil organic carbon enhancement, as compared to treeless farming systems. Most of these available reports on $\mathrm{C}$ sequestration in agroforestry systems are estimates of $\mathrm{C}$ stocks (Ajit et al., 2013). How much $\mathrm{C}$ is, or potentially could be, accumulated and stored in above and belowground compartments of Agroforestry system under different conditions of ecology and management. The estimates range from 0.29 to $15.21 \mathrm{Mg} \mathrm{ha}^{-1}$ year $^{-1}$ above ground, and 30-300 $\mathrm{Mg} \mathrm{C} \mathrm{ha}^{-1}$ up to 1 meter depth in the soil (Nair et al., 2010).

Homegardens agroforestry system has high carbon storage (sequestration) potential in their multiple plant species, especially in wood perennial species, and soil; they help in conservation of $\mathrm{C}$ stock in existing forests by alleviating the pressure on natural forest (Schroth et al., 2004). To some extent, in C substitution by reducing fossil-fuel burning through promotion of wood fuel production. Most reports indicated that the addition of a large proportion of the relatively high quantity of plant materials produced in a system will increase $\mathrm{C}$ stock in soils (Lal, 2004). Therefore it is reasonable to surmise that Homegardens will help substantially in C sequestration (Montagnini and Nair, 2004; Kumar, 2006). Most C sequestration reports also have disclaimers and caveats that lack of reliable inventories/estimates and uncertainties in the methods of estimation present serious difficulties. Thus, as in the case of other intangible and difficult to measure benefits and services, $\mathrm{C}$ sequestration benefit of Homegardens remains one of the 'potential benefits' that has not been even quantified, let alone exploited.

\section{Importance of ecosystem services}

Ecosystem service means flow of benefits for human well-being provided by natural ecosystems. In this context, ecosystem services span from tangible goods like wood, carbon sequestration, enhance soil fertility, wild life protection, supply of water quality, control of pests and diseases, biodiversity conservation, maintenance of recreational areas for hunting and tourism maintenance, agricultural products to non-material benefits like climate regulation and aesthetic features (Figure 3) (Kumar 2010; Kumar and Tripathi, 2017). The economics of ecosystems and biodiversity have emphasized the role that managed ecosytems paly in the delivery and maintenance of critical services and in fostering social-ecological resilience (Biggs et al., 2012). Agro-ecosystems capacity depends on the intensity of use and diversity of cropland (Jackson et al., 2007a, 2007b). The intimate association between the annual and perennial components enhances nutrient recycling and reduces vulnerability to soil erosion through nutrient pumping mechanism. Nutrient turnover is strongly influenced by 
the species composition and biomass of the tree components (Kumar and Nair, 2004; Allen et al., 2004; Seneviratne et al., 2006, Seneviratne et al., 2010). Unlike monoculture or dual component systems, the multi-species, multi-strata composition of Homegardens permits the enhancement in resource acquisition efficiency.

\section{Importance of traditional knowledge in homegardens}

The World Health Organization (WHO) has estimated that $80 \%$ population of developing countries relies upon traditional medicinalmostly plant drugs-for their primary health care needs (Fransworth and Soejarto, 1991). Local people have knowledge about the flora and fauna, their utility, interactions between the flora and fauna, the seasonal variations in the ecosystem and other such details of the functioning of the ecosystems. They understand the ecological process through experience and observation (Kumar et al., 2013, Kumar et al., 2014a, b; Kumar, 2014; Kumar, 2015b, c, d, e; Kumar and Mano, 2015). Homegardens being one of the earliest forms of agroforestry practiced in the tropics (Kumar and Nair, 2004), It is only logical to be expected that medicinal plants have been an essential component of these production systems. Indeed, the Homegardens make a substantial contribution to the supply of medicinal plants, which may be traded or consumed locally by the family or community (Albuquerique and Andrade, 2002). There is, however, no reliable data on the extent of Homegardens in different countries (Nair and Kumar, 2006), yields of medicinal plants, or products extracted and sold at national and international levels.

It is a known fact that many traditional communities in the tropical and subtropical countries have several traditional knowledge and practices to conserve natural ecosystems and associated biodiversity (Chandrashekara and Sankar, 1998; Ramakrishnan et. al., 2000). Similarly, many farming communities have of such traditional knowledge and practices for managing crop diversity and using the bioresources sustainably. Homestead farming is not an exception to this. For instance, cultivation of bamboo as a crop component in homesteads of Kerala has the strong traditional ecological base. Certain traditional practices of homestead bamboo cultivation and their benefits to farmers (Chandrashekara, 1996) are listed below also explain the management of crop species diversity in the system.

Thus the traditional Homegardens represent a typical example for agroforestry systems. This farming system no doubt is rich with inherent ecological, social, economic and cultural strengths. In this context, farming practices associated with Homegardens could also be adopted in the joint efforts of the forest department and local communities leading to eco-development, ecosystem rehabilitation and ecosystem recovery. This is because, tree planting and associated activities alone as the rehabilitation efforts in degraded forests near tribal settlements could not solve the problems of tribals in the long run. On the other hand, once the multispecies, multi-crop and multi-tier systems like that of homestead farming are adopted, there is every chance to ensure food security of the local tribal community, uplift of their economic and social status and also improvement of ecosystem health. Similarly, Homegardens can be regarded as the model in developing integrated social forestry. By utilizing the farmers' skills in managing and sustainable use of plant diversity, and by using ecologically, socially and culturally accepted species for planting, it is possible to make the social forestry programme more successful even in the difficult areas. Nearly half of the 41 weed species found in the 
Homegardens of Central Sulawesi, In India, seasonal weeds such as Phyllanthus amarus, Boerhaavia diffusa, Achyranthus aspera, Tribulus terrestris, Sida cordifolia, and Aerva lanata that occur both in cultivated fields (including Homegardens) and wild are collected for medicinal purposes (Rao et al., 1999). Kumar et al., (2014a) reported that 143 medicinal plant species found in Gujarat and among these, 78 species occur wild in forests or other forms of natural vegetation, 23 species grow as weed, 42 species are grown as cash crop for other plant based products and 22 species are cultivated as medicinal crop. Kumar $(2014 ; 2015$ c) found that 84 species of NTFPs and among these food (19), medicines (31), and raw materials for making implements (6) and also as a source of income (18) in Peechi-Vazhani Wildlife Sanctuary, Western Ghats, Kerala.

\section{Importance of future of homegardens}

The important of urban and Homegardens agroforestry and its implications for planning are not clearly understood by most planners and policymakers in the tropics region because of a lack of quantitative data on its nature, extent, and cultural and ecological significance. There is little sign of a continuation of the interest once shown by some city planners and administrators. Obviously, no one can accurately predict the future of an activity such as home gardening that is deeply rooted in ecological, socioeconomic, and cultural milieu of the land and its people.

Homegardens are no exception, they will certainly be affected by the changes happening in the local ecology, ecomics, and culture. The rate and extent of the impact of such changes will depend on a myriad of factors. Economic and cultural forces often pull the society and people's attitudes in opposite directions. Prompted by the lack of appreciation of the value of Homegardens in development paradigms and the trends towards commercialization of Homegardens and urban Homegardens, the question has been posed "are Homegardens becoming extict"? (Kumar and Nair, 2004). Wiersum (2006) argues that this illustrates that "the notion of socioeconomic sustainability of Homegardens should be interpreted as referring not only to their ability to contribute towards the livelihood needs of traditional rural dwellers, but also to their ability to adjust to the process of rural change".

If some farmers in periurban centers are attracted by the forces of economics to convert their Homegardens or sections of them to growing crops that can fetch money in the market, there will be an equally strong (if not stronger) section of farmers who are not attracted by the lure of money to abandon their age-old traditions. When, rather than if, some genetically modified crops find their way to Homegardens, that may not necessarily mean a proliferation of transgenic Homegardens-at least in the near future (Nair, 2006).

In fact, Homegardens is 'testing grounds' of many innovations of the gardeners, and today's gardens of long standing are a result of such continuous innovation and improvement. The migration of the youth to urban and even overseas centers in search of jobs and cash income, a common feature of home garden dominated societies, naturally raises concerns about the future of Homegardens, particularly the scope for bringing any technological innovations to the practice of home gardening. Homegardens will undergo changes; but they will not extinct; they will continue to exist with their mysterious, enigmatic charm to provide sustenance, satisfaction, income, and aesthetic appeal to many, and fascination to scientists who care to look at them. 
In conclusion, Homegardens agroforestry system is helping in conserving crop diversity, reducing the pressure on local natural forests by being a source of food, timber, fuel wood, fodder, medicinal plants etc. As already indicated crops derived from Homegardens is one element in a complex system of rural relationships where human beings are the main actors. However, during the last few years, throughout the tropics, a shift in the multiple cropping patterns of Homegardens towards mono-cropping has been observed. With radical changes in time preferences, there is a growing disinterest among farmers to deal with long gestation tree crops. There is a risk due to market instability and unresolved diseases like coconut wilt, quick wilt of pepper, phytophtora of arecanut etc. For better sustainable production of Homegardens, government's should be take positive actions such as launching of agroforestry extension activities, education and training for farmers on agroforestry, and supply of quality plant propagules and technical know-how, for attaining farmers to diverse varieties of crops in their homesteads. It may also be pointed out here that our primary and secondary and even higher institutions of learning do not have curricula on home garden agroforestry systems. Lack of solid research data to highlight the importance of crop combinations in homestead farming is another constraint in revitalizing traditional home garden agroforestry practices. Autoecological and synoecological properties of plant components, particularly trees, plant-plant interactions, economics of homestead farming, resources management and utilization and other aspects are yet to be studied systematically. This is possible only when the stress is given for conducting research on Homegardens at the same order of magnitude as that being given to control pests and diseases in cash crops and to breeding new varieties of rice.

\section{References}

Abdoellah, O.S., Hadikusumah, H.Y., Takeuchi, K., Okubo, S., and Parikesit 2006. Commercialization of Homegardens in an Indonesian village: vegetation compositions: A time-tested example of sustainable agroforestry. Springer Science, Dordrecht, pp 233-250.

Abebe, T., 2005. Diversity in home garden agroforestry systems of southern Ethiopia. Wageningen University, the Netherlands. Tropical Resource Management, Paper No. 59: $143 p$.

Abebe, T., Wiersum, K.F., Bongers, F., and Sterck, F. 2006. Diversity and dynamics in Homegardens of southern Ethiopia. In: Kumar, B.M. and Nair, P.K.R. (eds), Tropical Homegardens: A time-tested example of sustainable agroforestry, pp 123-142. Springer Science, Dordrecht.

Ajit, Dhyani, S.K., Ram Newaj, Handa, A.K., Prasad, R., Alam, B., Rizvi, R.H., Gupta, G., Pandey, K.K., Jain, A., and Uma 2013. Modeling analysis of potential carbon sequestration under existing agroforestry systems in three districts of Indo-gangetic plains in India. Agroforest Systems. 87: 1129-1146.

Albuquerique, de U.P., and Andrade, L de H.C. 2002. Conhecimento botánico tradicional e conservação em uma área de caatinga no estado de Pernambuco, nordeste do Brasil. Acta Botanico do Brasil. 16: 273-285.

Arifin, H.S., Munandar, A., Schultink, G., and Kaswanto, R.L. 2012. The role and impacts of small-scale homestead Agroforestry system (Pekarangan) on household prosperity: an analysis of agro-ecological zones of Java, Indonesia. International Journal of Agricultural Science. 2(10): 896914.

Asahira, T., and Yazawa, S. 1981. Report of the scientific survey on traditional cropping systems in tropical Asia. Part I. India and Sri Lanka. Center for Southeast Asian Studies, Kyoto University. Kyoto.

Babu, K.S., Jose, D., and Gokulapalan, G. 1992. Species diversity in a Kerala home garden. Agroforestry Today. 4: 15.

Biggs, R., Schlüter, M., Biggs, D., Bohensky, 
E.L., BurnSilver, S., Cundill, G., Dakos, V., Daw, T.M., Evans, L.S., Kotschy, K., et al., 2012. Toward principles for enhancing the resilience of ecosystem services. Annual Review of Environment and Resources, 37: 421-448.

Brierley, J.S. 1976. Kitchen gardens in the West Indies, with a contemporary study from Grenada. Journal of Tropical Geography. 43: 33-40.

Chandrashekara, U.M. 1995. Ecological and economic benefits of tree components in homestead farming systems of Kerala. In: Pillai, P.P., Nair, R.P. (Eds.) Undestanding Ecologically Sustainable Economic Development. Institute of Planning and Applied Economic Research, Dr. John Mathai Centre, Thrissur. pp. 104-108.

Chandrashekara, U.M. 1996. Strengths and weaknesses of traditional systems of bamboo cultivation in rural Kerala. Agroforestry Forum. 7: 21-23.

Chandrashekara, U.M., and Baiju, E.C. (2010). Changing pattern of species composition and species utilization in Homegardens of Kerala, India. Tropical Ecology. 51(2): 221-233.

Chandrashekara, U.M., and Sankar, S. 1998. Ecology and management of sacred groves in Kerala, India. Forest Ecology and Management. 112: 165-177.

Chandrashekara, U.M., Sankar, S., Shajahan, P.K., Blowfield, M.E. and Boa, E.R. 1997. Fencing patterns in Homegardens of Kerala, India: a case study. Range Management \& Agroforestry. 18: 41-53.

Coomes, O.T., and Ban, N. 2004. Cultivated plant species diversity in home garden of an Amazonian peasent village in northeastern Peru. Economic Botany. 58: 420-434.

Das, T., and Das, A.K. 2005. Inventorying plant biodiversity in Homegardens: A case study in Barak Valley, Assam, North East India. Current science. 89(1): 155-163.

Devi N.L., and Das, A.K. 2012. Diversity and utilization of tree species in Meitei Homegardens of Barak valley, Assam. Journal of Environmental Biology. 34: 211217.

Dunkelman, I., and Davidson, J. 1988. Women and Environment in the Third World:
Alliance for the Future. Earthscan Publications Limited. London.

Eyzaguirre, P., and Watson, J. 2001. Homegardens and agrobiodiversity: an overview across regions. In: Watson, J.W. and Eyzaguirre, P.B. (eds) Homegardens and in situ conservation of plant genetic resources in farming systems. Proceedings of the Second International Homegardens Workshop, 17-19 July 2001, Witzenhausen, Germany. IPGRI, Rome, 10-13.

Farnsworth, N.R., and Soejarto, D.D. 1991. Global importance of medicinal. In: Akerele, O., Heywood, V. and Synge, H. (eds), The conservation of medicinal plants, Cambridge University Press, Cambridge, pp. 25-51.

Fernandes, E.C.M., and Nair, P.K.R. 1986. An evolution of the structure and function of tropical Homegardens. Agricultural Systems. 21: 279-310.

Galluzzi, G., Eyzaguirre, P., and Negri, V. 2010. Homegardens: neglected hotspots of agrobiodiversity and cultural diversity. Biodiversity and Conservation. 19: 36353654.

Gariya, K., Dwivedi, G.K., and Kumar, V. 2017. Agrobiodiversity, Composition and Functional Characteristics of Homegardens in Bhimtal block of Nainital district, Uttarakhand, India. International Journal of Agriculture, Environment and Biotechnology. Vol. 10 (Accepted).

Gariya, K., Dwivedi, G.K., Kumar, V., and Tewari, S.K. (2016). Socio-economic Characteristics of Homegardens in Bhimtal block of Nainital District, Uttarakhand, India. International Journal of Agriculture, Environment and Biotechnology. 9(6): 1001-1013.

Huston, P. 1985. 'Third World Women Speak Out'. Asian Women's Research and Action Network, Davao City, Philippines.

Jackson, I.E., Pascual, U., and Hodgkin, T. 2007a. Utilizing and conserving agrobiodiversity in agricultural landscapes. Agriculture, Ecosystems and Environment. 121: 196210.

Jackson, I.E., Pascual, U., Brussaard, L., de Ruiter, P. and Bawa, K.S. 2007b. Biodiversity in agricultural landscapes: 
Investing without losing interest. Agriculture, Economics and Environment. 121: 193-195.

Jose, D. 1991. Homegardens of Kerala: Small and marginal farmers' response to change in agrarian structure and environmental constraints. M.Sc. thesis, Agricultural University of Norway.

Jose, D., and Shanmugaratnam, N. 1993. Traditional Homegardens of Kerala: A sustainable human ecosystem. Agroforestry Systems, 24: 203-213.

K.S.L.B. (Kerala State Landuse Board) 1989. Land resources and land use in Kerala. Kerala State Land Use Board, Trivandrum.

Kehlenbeck, K., and Maass, B.L. 2004. Crop diversity and classification of Homegardens in Central Sulawesi, Indonesia. Agroforestry Systems. 63: 53-62.

Krishanankutty, C.N. 1998. Socio-economic and ecological aspects of developing bamboo resources in homesteads of Kerala. Part 2. Economic and Management aspects. KFRI Research Report 125, Kerala Forest Research Institute, Peechi, Kerala.

Krishankutty, C.N. 1990. Demand and supply of wood in Kerala and their future trends. KFRI Research Report 67, Kerala Forest Research Institute, Peechi, Kerala.

Kumar, B.M. 2006. Carbon sequestration potential of tropical Homegardens. In: Kumar, B.M. and Nair, P.K.R. (eds), Tropical Homegardens: A time-tested example of sustainable agroforestry, Springer Science, Dordrecht, pp 185-2004.

Kumar, B.M. 2011. Species richness and aboveground carbon stocks in the Homegardens of central Kerala, India. Agriculture, Ecosystems and Environment. 140: 430-440.

Kumar, B.M., and Nair, P.K.R. 2004. The enigma of tropical Homegardens. Agroforestry Systems. 61: 135-152.

Kumar, B.M., George, S.J., and Chinnamani, S. 1994. Diversity, structure and standing stock of wood in the Homegardens of Kerala in Peninsular India. Agroforestry Systems. 25: 243-262.

Kumar, P. 2010. The Economics of Ecosystems and Biodiversity: Ecological and Economic Foundations. An Output of TEEB: The
Economics of Ecosystems and Biodiversity; Earthscan: London, UK, 2010.

Kumar, V. 2014. Impact of Non Timber Forest Produces (NTFPs) on rural tribe's economy in Peechi Vazhani Wildlife Sanctuary, Western Ghats, Kerala. International Journal of Forest Usufructs Management. 15(2): 80-100.

Kumar, V. 2015a. Estimation of Carbon Sequestration in Agroforestry Systems. Van Sangyan. 2(5): 17-22.

Kumar, V. 2015b. Impact of Non Timber Forest Produces (NTFP's) of Food and Livelihood Security: An Economic Study of Tribal Economy in Dang's district of Gujarat, India. International Journal of Agriculture, Environment and Biotechnology. 8(2): 387404.

Kumar, V. 2015c. Role of Non Wood Forest Products in Tribal Economy of Gujarat. International Journal of Forest Usufructs Management. 16(1): 67-75.

Kumar, V. 2015d. Ethno-Medicinal Plants in Five Forest Ranges in Dang's District, South Gujarat, India. Indian Journal of Tropical Biodiversity. 23(2): 148-156.

Kumar, V. 2015e. Ethnomedicines of Malayan Tribes of Southern Region of Kerala, India. In: Sanjeev kumar (Eds), Recent Advances in Ethnobotany, Deep Publication, New Delhi, pp 173-185.

Kumar, V. 2016. Multipurpose Agroforestry Systems in Tropics Region. Nature Environment and Pollution Technology. 15(2): 365-376.

Kumar, V. 2018. Agrobiodiversity, Structural Compositions and Species Utilization of Homegardens in Humid Tropics, Kerala, India. Tropical Ecology (Accepted).

Kumar, V., Ajeesh, R., Revale, A.A., and Nayak, M.R. 2014b. Medicinal Plants: Cultivation to Value Addition: Problems and Issues. Research and Reviews. Journal of Agriculture and Allied Sciences. 3(3): 6371.

Kumar, V., and Desai, B.S. 2014. Indigenous Knowledge of Wild Plant Species of South Gujarat. In: Sanjeev kumar (Eds), Ethnobotanical studies in India, Deep Publication, New Delhi, pp 303-310.

Kumar, V., and Mano, G. 2015. Ethno-Medico- 
Biology of Cuddalore District, Tamil Nadu, India. In: Sanjeev kumar (Eds), Recent Advances in Ethnobotany, Deep Publication, New Delhi, pp 209-214.

Kumar, V., and Tripathi, A.M. 2017. Vegetation Composition and Functional Changes of Tropical Homegardens: Prospects and Challenges. In: Gupta SK, Panwar P and Kaushal R (Eds), Agroforestry for increased production and livelihood security. New India Publishing Agency, New Delhi, pp-475-505.

Kumar, V., Babu, S., Revale, A. K., Meena, R.K., Ranjan, M.K., and Desai, B.S. (2014a). Cultivation of medicinal plants in natural ecosystem in Gujarat (India): constraints and conservation need. Journal of Plant Development Sciences. 6(3): 425-435.

Kumar, V., Desai, B.S., and Ajeesh, R. 2013. Ecology of Rare and Endangered plant species of Dang's Forest, South Gujarat. LAP LAMBERT Academic Publishing, Germany.

Kumar, V., Niyas, P., and Unnithan, S.R. 2016. Medicinal plants based on intercrops Homegardens system. Van Sangyan. 3(7): 20-26.

Kunhamu, T.K., Ajeesh, R., and Kumar, V. 2015. Floristic Analysis of Peri-Urban Homegardens of Southern Kerala, India. Indian Journal of Ecology. 42(2): 300-305.

Lakshmi, G. and Joseph, A. 2017. Soil microarthropods as indicators of soil quality of tropical Homegardens in a village in Kerala, India. Agroforestry Systems. 91(3): 439-450.

Lal, R. 2004. Soil carbon sequestration impacts on global change and food security. Science. 304: 1623-1627.

Leiva, J.M., Azurdia, C., Ovanda, W., Lopez, E., and Ayala, H. 2002. Contributions of Homegardens to in situ conservation in traditional farming systems- Guatemalan component. In: Watson, J.W. and Eyzaguirre, P.B. (eds), Homegardens and in situ conservation of plant genetic resources in farming systems. Proceeding of the second International Homegardens workshop, Witzenhausen, Germany, International Plant Genetic Resources Institute, Rome, pp 56-72.
McNeely, J.A. 2004. Nature vs. nurture: Managing relationships between forests, agroforestry and wild biodiversity. Agroforestry system. 61: 155-165.

Mendez, V.E., Lok, R., and Somarriba, E. 2001. Interdisciplinairy analysis of Homegardens in Nicaragua: micro-zonation, plant use and socioeconomic importance. Agroforestry Systems. 51: 85-96.

Michon, G., and Marry, F. 1994. Conservation of traditional village gardens and new economic strategies of rural households in the area of Bogor, Indonesia. Agroforestry System. 25: 31-58.

Millat-e-Mustafa, M., Teklehaimanot, Z. and Haruni, A. K. O. (2002). Traditional uses of perennial homestead garden plants in Bangladesh. Forests Trees Livelihoods. 12: 235-256.

Montagnini, F., and Nair, P.K.R. 2004. Carbon sequestration: An under-exploited environmental benefit of Agroforestry systems. Agroforestry System. 61: 281-298.

Mulas, M.G., Quiroz, C., Perez, S.D.M., Rodriguez, D., Perez, T., Marques, A., and Pacheco, W. 2004. Conservacion in situ de diversas especies vegetales en 'conucos' (Homegardens) in the states of Carabobo y Trujillo de Venezuela. Plant Genetic Resources Newsletter. 137: 1-8.

Murthy, I.K., Gupta, M., Tomar, S., Munsi, M., Tiwari, R., Hegde, G.T., and Ravindranath, N.H. 2013. Carbon sequestration potential of agroforestry systems in India. Journal of Earth Science \& Climate Change. 4(1): 1-7.

Nair, M.A., and Sreedharan, C. 1986. Agroforestry farming system in the homesteads of Kerala, Southern India. Agroforestry Systems. 4: 339-363.

Nair, P.K.R. 2006. Agroforestry for sustainability of lower-input land use systems. Journal of sustainable crop production. 19(1): 25-47.

Nair, P.K.R. 2008. Agroecosystem management in the $21^{\text {st }}$ century: It is time for a paradigm shift. Journal of Tropical Agriculture. 46(1\&2): 1-12.

Nair, P.K.R., Nair, V.D., Kumar, B.M., and Showalter, J.M. 2010. Carbon sequestration in agroforestry systems. Advances in Agronomy. 108: 237-307.

Ninez, V.K. 1987. Household gardens: theoretical 
considerations on an old survival strategy. Agricultural Systems. 23: 167-186.

Pandey, C.B., Lata, K., Venkatesh, A., and Medhi, R.P. (2006). Diversity and species structure of Homegardens in south Andaman. Tropical Ecology. 47: 251-258.

Peyre, A., Guidal, A., Wiersum, K.F., and Bongers, F. 2006. Home garden dynamics in Kerala, India. In: Kumar, B.M. and Nair, P.K.R. (eds), Tropical Homegardens: A time-tested example of sustainable agroforestry, Springer Science, Dordrecht, pp 87-103.

Quiroz, C., Gutierrez, M., Rodriguez, D., Perez, D., Ynfante, J., Gamez, J., Perez, de Fernandez, T., Marques, A., and Pacheco, W. 2002. Homegardens and in situ conservation of agrobiodiversityVenezuelan component. In: Watson, J.W., Eyzaguirre, P.B. (eds), Homegardens and in situ conservation of plant genetic resources in farming systems. Proceeding of the second International Homegardens workshop, Witzenhausen, Germany, International Plant Genetic Resources Institute, Rome, pp 73-82.

Ramakrishnan, P.S., Chandrashekara, U.M., Elouard, C., Guilmoto, C.Z., Maikhuri, R. K., Rao, K.S., Sankar, S., and Saxena, K.G. 2000. Mountain Biodiversity, Land use Dynamics, and Traditional Ecological Knowledge. UNESCO, New Delhi. Oxford $\&$ IBH Publ. New Delhi.

Rana, P., Tewari, S.K., and Kumar, V. 2016. Floristic structure, composition and functional characteristics of home garden in Garhwal region, Uttarakhand, India. International Journal of Agriculture, Environment and Biotechnology. 9(6): 1049-1059.

Rana, P., Tewari, S.K., and Kumar, V. 2017. Socio-economic Characteristics of Homegardens in Garhwal Region of Uttarakhand, India. International Journal of Agriculture, Environment and Biotechnology. Vol. 10 (Accepted).

Rao, M.R., and Rajeswara Rao, B.R. 2006. Medicinal plants in tropical Homegardens. Vol. 03: 205-232. In: Kumar, B.M. and Nair, P.K.R. 2006 (Ed.). Tropical Homegardens: A time tested example of sustainable agroforestry. Springer, Netherlands.

Saha, K.S., Nair, P.K.R., Nair, D.V., and Kumar, B.M. (2009). Soil carbon stock in relation to plant diversity of Homegardens in Kerala, India. Agroforestry Systems. 76: 5365.

Sahoo, U.K., Rocky, P., Vanlalhriatpuia, K., and Upadhyaya, K. 2010. Structural diversity and functional dynamism of traditional Homegardens of North-East India. The Bioscan. 1: 159 -171.

Saikia, P.M., Choudhury, B.I., and Khan, M.L. 2012. Floristic composition and plant utilization pattern in Homegardens of Upper Assam, India. Tropical Ecology. 53(1): 105-118.

Sankar, S. and Chandrashekara, U.M. 2002. Development and testing of sustainable agroforestry models in different agroclimatic zone of Kerala with emphasis on socio-cultural, economic, technical and institutional factors affecting the Sector. KFRI Research Report 234. Kerala Forest Research Institute, Peechi, Kerala.

Sankar, S., and Chandrashekara, U.M. 1997. Agroforestry systems. In: K. Balachandran, Thampi, N. M. Nayar and C. N. Nair. (Eds.) The Natural Resources of Kerala. WWF India, Kerala State Office, Thiruvananthapuram. pp. 473-477.

Schroth, G., da Fonseca, A.B., Harvey, C.A., Gascon, C., Vasconcelos, H.L., Izac, N. (eds). 2004. Agroforestry and biodiversity conservation in tropical landscapes. Island Press, Washington, DC. 523p.

Senanayake, R.L., Sangakkara, U.R., Pushpakumara, D.K.N.G., and Stamp, P. 2009. Vegetation Composition and Ecological Benefits of Homegardens in the Meegahakiula Region of Sri Lanka. Tropical Agricultural Research. 21(1): 1-9.

Seneviratne, G., Kuruppuarachchi, K.A.J.M., Somaratne, S., and Seneviratne, K.A.C.N. 2010. Nutrient cycling and safety-net mechanism in the tropical Homegardens. International Journal of Agricultural Research. 5(7):529-542.

Seneviratne, G., Kuruppuarachchi, K.A.J.M.S., Somaratne, S., and Seneviratne, K.A.C.N. 2006. Nutrient cycling and safety-net 
mechanism in the tropical Homegardens. International Journal of Agricultural Research. 1(2):169-182.

Shanavas, A. and Kumar, B.M. 2003. Fuelwood characteristics of tree species in the Homegardens of Kerala, India. Agroforestry Systems. 58:11-24.

Shrestha, P., Gautam, R., Rana, R.B., and Sthapit, B.R. 2002. Homegardens in Nepal: Status and scope for research and development. In: Homegardens and in situ conservation of plant genetic resources in farming systems (Eds.: JW Watson, PB Eyzaguirre). Witzenhausen, Germany/IPGRI, Rome, pp. 105-124.

Simons, A.J., and Leakey, R.R.B. 2004. Tree domestication in tropical agroforestry. Agroforestry System. 61: 167-181.

Soemarwoto, O. 1987. Homegardens: a traditional agroforestry system with a promising future. In Stepper, H.A. and Nair, P.K.R, (eds), Agroforestry: A decade of development, ICRAF, Nairobi, pp 157-170.

Soumya, M., Nair, P.K.R., and Long, A.J. 2007. An assessment of ecological diversity in Homegardens: a case study from Kerala state, India. Journal of Sustainable Agriculture. 29(4): 135-153.

Sunwar, S., Thomstrom, C.G., Subedi, A., and Bystrom, M. 2006. Homegardens in western Nepal: opportunities and challenges for on-farm management of agrobiodiversity. Biodiversity and
Conservation. 15: 4211-4238.

Swift, M.J., and Anderson, J.M. 1993. Biodiversity and ecosystem function in agricultural systems. In: Schulze, E.D. and Mooney, H.A. (eds), Biodiversity and ecosystems function, Springer, Berlin, pp $15-42$.

Torquebiau, E. 1992. Are tropical agroforestry Homegardens sustainable? Agriculture, Ecosystems \& Environment. 41: 189-207.

Torquebiau, E., and Penot, E. 2006. Ecology versus economics in tropical multistrata agroforests. Vol. 03: 269-282. In: Kumar BM, Nair PKR 2006 (Ed.). Tropical Homegardens: A time tested example of sustainable agroforestry. Springer, Netherlands.

Wiersum, K.F. 1995200 years of sustainability in forestry: lessons from history. Environmental Management. 19: 321-329.

Wiersum, K.F. 2004. Forest gardens as an 'intermediate' land use system in the nature-culture continuum: characteristics and future potential. Environmental Management. 61: 123-134.

Wiersum, K.F. 2006. Diversity and change in home garden cultivation in Indonesia. In: Kumar, B.M. and Nair, P.K.R. (Eds.), Tropical Homegardens: A time-tested example of sustainable agroforestry, Springer Science, Dordrecht, pp 13-24.

\section{How to cite this article:}

Vikas Kumar and Anjali Tiwari. 2017. Importance of Tropical Homegardens Agroforestry System. Int.J.Curr.Microbiol.App.Sci. 6(9): 1002-1019. doi: https://doi.org/10.20546/ijcmas.2017.609.122 